\title{
33. Navigating the supervisory relationship: the case of the disappearing supervisors
}

\section{Vicki Webster}

It's that time of year when students are asked to provide the university with feedback on whether they have experienced any problems/ difficulties with their supervision that may have impeded their progress with their doctoral thesis. Overall, I have received good support from my supervisors - when I can catch them. On reflection, the key difficulty I am experiencing in supervision is not being able to access the support I need at the stages of my thesis when I need it. Working full time and studying part time, my research thesis is fitted around work projects and commitments. Therefore, there are stages when my thesis is stalled when I am in a critical stage of study design, data collection or analysis, when I have an urgent query or issue to address. I'm thinking I don't really know what's normal supervision practice in relation to my issue, or if my expectations are realistic. As I'm a mature-aged student, is there an expectation I'll be more self-sufficient? Will I be courageous and say it as it is, or will I let the problem slide?

This was the key dilemma I experienced with the supervision of my doctorate. In this chapter, I will share the background to my issue, what happened and how I responded to my frustrations, my contribution to my issue, the role of peer networks to augment supervision, and lessons learned from my experience.

\section{BACKGROUND TO MY SUPERVISION ISSUE}

I'm the first person in my family to undertake doctoral study. I chose to study part time to cater for family (partner and aging parents) and work commitments (as primary financial provider, maintaining my income was a priority). Therefore, I sought out a research programme that offered me 
flexibility in how, when and where I participated; this seemed the most efficient way to integrate career, life and study (Offerman, 2011).

I came to my research $\mathrm{PhD}$ study with a view to enhancing my existing career. I did not intend to transition to a full-time academic career, but I did think it might lead to an opportunity to do some part-time teaching in the future. I wanted to study a problem I had observed many times in organisations throughout my career, so I had insight and experience in my research topic. I was keen to apply the learnings from my research to an organisational context. Therefore, I was looking for supervisors who would be not only discipline experts, but also facilitators, coaches and, over time, colleagues (Deuchar, 2008).

Over the course of my doctorate (eight years part time) I had four formal supervisors and many informal supervisors. I commenced with my initial principal supervisor in the same discipline I was trained in, which takes quite a narrow theoretical perspective to my research issue, and, because of the 'real world' nature of my research topic, I chose my secondary supervisor from another discipline that takes a broader social perspective. My secondary supervisor contracted up front the limitations of their supervision, to review each draft chapter once and then conduct one review of the whole thesis at the end, including a review of any journal article drafts they were involved in. At the time, this seemed reasonable, as I had my principal supervisor to provide a constant level of supervision. Initially I scoped out five research studies. Both my principal and secondary supervisors advised me this was too ambitious, but it took me some time to pay heed to their advice.

\section{WHAT HAPPENED}

Studying part time as an external student meant I interacted with my supervisors on a part-time, intermittent basis. Due to my personal need for autonomy, I carried out my doctoral project management and research preparation tasks quite independently in the early stages of my doctorate. I was clear on my topic and research question - however, the scope needed some refining before considering methodology. Where I particularly needed supervisor input was on my research skills: research design, data collection and statistical analysis. Although it was not clearly articulated at that time, I also needed my supervisors to be available and responsive when I needed them.

My initial principal supervisor was an ideas person. As a chronic 'achiever', I'd go to our meetings prepared with my agenda items and questions for discussion, and before I knew it the conversation had 
veered off on a radical and previously unexplored direction. Unbeknownst to me, this was exactly what I needed at the conceptualisation phase of my thesis. I was able to complete the first small study as part of my confirmation, a university process where I presented on my topic and proposed research agenda in order to obtain approval to proceed with my research. Together we scoped out my second study, a qualitative online survey.

What worked less well were my initial principal supervisor's constant overseas visits and sabbaticals for weeks at a time and with no notice. At commencement I was aware supervisors take annual leave and travel away to attend conferences, but, due to my lack of exposure to academia, I was unaware that they regularly took sabbaticals. 'Just email me if you have a query,' he would say, and into the black hole he would go, never to be heard from again until he returned to the university. Not fatal at that early stage, but frustrating. So, I sought informal supervision by other supervisors at the school. I bounced around the supervision team within the school looking for a quick solution to my research questions, given they were from the same discipline as me. I soon discovered they each had their own theoretical lens with which they approached my topic. Confusion reigned supreme. Just when I thought I had settled on an approach to my topic, another idea or lens would be provided that required a new literature review, only for me to come back to my initial approach as my preferred option. Given work and study priorities, this 'time wasting' was very frustrating for me. I felt I was spinning my back wheels and getting nowhere. When my initial principal supervisor returned, we would pick up where we left off, until his next overseas visit.

A couple of years into my candidature, my initial principal supervisor left the university to move overseas permanently (in hindsight, the reason for his many overseas visits becoming clear), and I moved on to a replacement principal supervisor. By this stage, I was in the implementation stage for my second study and the research design stage for my third study. My second principal supervisor, also from the same discipline as me, was an expert in the type of longitudinal intervention I was proposing to conduct, so I was excited to be moving from conceptualising the project into collecting the data. We contracted well up front from the point of view of agreeing a plan of work, how we would be project managing the research studies and thesis writing, being clear on milestones and outputs. She again advised me that I was overly ambitious in my proposal of completing five studies, but I wasn't ready to give them up just yet. Alas, at our next supervision meeting, when we were discussing how we would work together, she advised me, 'You know I'm 
about to go on maternity leave, but you can email me if you have a query.' Oh no, not again. When she did go on maternity leave, I did not feel comfortable bothering her, given she was dealing with the arrival of her first baby. I felt my research questions were relatively unimportant in the big scheme of things. So, again, I sought informal supervision from others in the department, but as I was at a critical stage of my research design and data collection, where prior knowledge of what we were trying to achieve was essential, they were less able to assist me.

In the meantime, the approach of having a secondary supervisor from another discipline was working well from one perspective, especially when conceptualising research questions and when writing up thesis chapters and journal articles. Having been away from academic writing for over seven years, I was finding moving away from business writing a struggle. My secondary supervisor could clearly articulate the reader's journey (i.e. use of jargon and long-winded, imprecise or confusing writing). She hammered home the 'So what?' factor. She really helped me find my voice and my point of view, and exponentially improved the quality of my academic writing through her direct and timely feedback. However, when deciding on research design, methodologies and statistical analyses, having a supervisor from a different discipline started to seem a less effective way to go. Each supervisor had a different point of view on the best way forward.

Being impatient, I surged ahead with my research on very limited supervision and lived to bear the unintended consequences of doing so. My second principal supervisor came back from maternity leave, reviewed my progress in data collection on my third study and we 'patched up' my research design as best we could. Then ... 'I'm going on sabbatical, but' - you guessed it - 'just email me if you need anything.' While she was more available during this period than when on maternity leave, by now I was moving into data analysis, so was able to seek external support. I arranged with my second principal supervisor to engage a third formal supervisor from my discipline to assist me. All this going back and forth with supervisors played havoc with my ambitious and, in hindsight, ridiculous self-imposed timeline.

On reflection, there were times when my innate independence worked well, as I took ownership of my research, but at times I forged ahead when it would have been better to wait and discuss my progress with my principal supervisor. As I was writing up my thesis, I kept checking in with my principal supervisor (a bit 'gun shy' after the issues with my third study design). However, eventually, I recognised there had been a transition - the responsibility for my thesis writing sat with me - and I needed to make the decisions, and not over-rely on my supervisors' input. 


\section{SEEKING ADDITIONAL SUPPORT THROUGH PEER NETWORKS}

As I was an external student, it took me longer than most to realise the importance of building a network of peers (Jairam \& Kahl, 2012; Pilbeam et al., 2013). As an achievement-oriented driver, I like to be in control, so I tended to procrastinate whenever I felt out of control, which for me was during data collection, especially on my longitudinal study, where I knew there was often significant attrition over time (and yes, it was bad), and when engaging with the statistical analyses. I needed support through these difficult times, and I felt quite disconnected from my PhD colleagues. Most of the time I was working off site and I had no formal classes in which I would meet other $\mathrm{PhD}$ students. I did take advantage of workshops to assist with all aspects of designing and completing my research and thesis, but colleagues from my discipline were not at those workshops.

I was into my fourth year of research when my second principal supervisor invited me to monthly get-togethers with all her doctoral students, which I was able to attend every two to three months. Through this process, I was able to align with a small number of doctoral candidate colleagues. This really helped my motivation. The social support of validating my frustrations and challenges was helpful, especially from those who were ahead of me in progress with their thesis. The benefit of getting to know my academic colleagues was that I felt comfortable asking for their assistance on minor queries without bothering my supervisor. I built some great networks preparing for conference presentations as part of a stream of co-presenters. One of my colleagues had a goal to attend and present at the International Conference on Applied Psychology (ICAP) in Paris, which built momentum until there was a group of us heading to Paris, presenting our papers under the watchful eye of our supervisor. This really inspired us to achieve our doctoral milestones so we could present the preliminary results from our studies to get feedback on our work (Pilbeam et al., 2013). Working together on our presentations was helpful and brought us together as colleagues. So, if the university doesn't provide the mechanisms for a support network of colleagues, make your own. Seek out those at all stages of their thesis, so you can hear about the minefields, tips and tricks along the way. They will remind you when it's time to take a break and refresh or give you a kick up the bum when it's time to get on with it. 


\section{SUPERVISION AND THESIS SUBMISSION}

I submitted a thesis with publication. My supervisors were very helpful in critiquing and assisting with rewriting journal submissions. Once a journal article was submitted or accepted, I could insert the submission or published article as a thesis chapter 'as is'. So, my introduction and literature review took the form of a traditional thesis, but for those studies that were submitted for publication or published, the journal article could be inserted as a chapter just as it was to be published, without editing for the thesis. For those studies not published, the chapters were written up in the traditional thesis style. Two out of my three studies were inserted as journal article chapters (yes, I finally reduced the scope from five to three studies). Of course, being accepted for review and/or publication was a difficult task given the rejection rates of good journals. Again, encouragement from my supervisors was essential. When I reacted emotionally to constructive feedback from reviewers, I'd put it away for 36 hours, and when I took it out and looked at it again it was never as bad as I'd initially thought - I was back into problem-solving mode. I could then arrange a meeting with my second principal supervisor and we collaboratively chose the best response to the feedback.

And so, the thesis project dragged on - journal article submissions ... thesis rewrites ... article rewrites ... thesis rewrites. Then, after more than seven years of part-time research and study, I just ran out of steam. I did one last big push and submitted my thesis, when I knew it needed more editing. Consequently, significant revisions were required before I finally passed. My supervisors' support through the lengthy evaluation phase was essential.

What worked well in my supervision experience was the level of technical expertise each supervisor held, as they were personally active researchers, with international networks, which influenced decisions on journal submissions and conference presentations. Feedback on drafts was provided promptly within a week or two, especially for journal articles. My second principal supervisor also contributed external examiners' names for consideration.

\section{LESSONS LEARNED}

On reflection, I needed different levels of structure and support from my supervisors throughout the doctoral journey, although I never explicitly realised this or negotiated it at the commencement of my supervisory relationships (I guess you don't know what you don't know). I sought 
and was very satisfied with the level of autonomy granted to me by my supervisors at the beginning and end phases of my doctorate, and I needed quite extensive technical support during the middle years of data collection and analyses, when I felt there was less availability and responsiveness from my supervisors (Deuchar, 2008). In the end, I did raise the issue of the difficulty of accessing supervision at the times when my supervisor/s were away from the university and submitted my comments in the annual survey.

So, what have I learned on my doctorate journey?

1. Ensure your principal and secondary supervisors are from within your discipline. If your university allows additional supervisors to be engaged, there is value in choosing a supervisor from a different discipline.

2. Ask up front what leave and sabbaticals your supervisors plan on taking, and identify times when both your principal and secondary supervisors will be unavailable. Co-create a backup plan.

3. Listen to your supervisors, especially when they tell you the planned project is too large.

4. You will get faster feedback from your supervisor when you are co-writing journal articles. After all, this is a key performance criterion for them. Be guided by your supervisor on the best journals to publish your study/topic. I was ready to give up and my supervisors encouraged me to keep submitting - eventually one of my papers was accepted.

5. Reviewer feedback is just as useful as supervisor feedback. Take some time out after receiving reviewer feedback to get over yourself, and then discuss the comments with your supervisor/s.

6. Even if you're a part-time student, make sure you get to know other doctoral students early on and find ways to connect with them. Learn from their achievements and mistakes (especially those further on in the $\mathrm{PhD}$ journey).

\section{REFERENCES}

Deuchar, R. (2008). Facilitator, director or critical friend? Contradiction and congruence in doctoral supervision styles. Teaching in Higher Education, 13(4), 489-500.

Jairam, D., \& Kahl Jr., D.H. (2012). Navigating the doctoral experience: The role of social support in successful degree completion. International Journal of Doctoral Studies, 7, 311-30. 
Offerman, M. (2011). Profile of the non-traditional doctoral degree student. New Directions for Adult and Continuing Education, 2011(129), 21-30.

Pilbeam, C., Lloyd-Jones, G., \& Denyer, D. (2013). Leveraging value in doctoral student networks through social capital. Studies in Higher Education, 38(10), 1472-89. 